\title{
Effects of feed additives on nutrient digestibility and the bacterial status of faeces in pigs
}

\author{
K. Lipiński ${ }^{1,4}$, C. Purwin ${ }^{1}$, J. Tywończuk ${ }^{1}$, Z. Zduńczyk ${ }^{2}$, \\ M. Wróblewska ${ }^{2}$ L. Laniewska-Trokenheim ${ }^{3}$ and I. Warmińska-Radyko ${ }^{3}$ \\ University of Warmia and Mazury in Olsztyn, \\ ${ }^{1}$ Department of Animal Nutrition and Feed Management \\ Oczapowskiego 5, 10-718 Olsztyn \\ ${ }^{3}$ Department of Industrial and Food Microbiology \\ Pl. Cieszyński 1, 10-726 Olsztyn, Poland \\ ${ }^{2}$ Institute of Animal Reproduction and Food Research, Polish Academy of Sciences, \\ Division of Food Science \\ Tuwima 10, 10-747 Olsztyn, Poland
}

\section{ABSTRACT}

The effects of different feed additives (flavomycin, oregano, MOS and Lactobacillus plantarum) added to diets for growing pigs $(20 \mathrm{~kg} \mathrm{BW})$ on nutrient digestibility and the microbial status of faeces were investigated in the study.

Diet supplementation with different feed additives had no effect on the digestibility of most nutrients. Faecal bacterial populations (E. coli, Lactobacilli spp.) were not affected by diet composition. Diets supplemented with oregano, MOS and L. plantarum did not increase the activity of microbial enzymes or the concentration of short-chain fatty acids in the faeces of pigs.

KEY WORDS: growing pigs, feed additives, digestibility, microbial status of faeces

\section{INTRODUCTION}

Good health and high productivity of animals depend, among others, on a proper balance between beneficial and harmful microorganisms colonizing the alimentary tract (Hillman, 2001). The composition and activity of the intestinal microflora can be altered by the current state of gut physiology, diet composition and dietary manipulations, such as the use of feed additives and antibiotics.

The aim of the present study was to determine the effects of different feed additives (antibiotics, essential oils, probiotics, and prebiotics) in diets for growing pigs on nutrient digestibility and the microbial status of faeces.

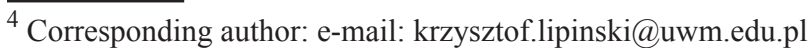




\section{MATERIAL AND METHODS}

A digestibility experiment was carried out on 25 growing pigs with average body weights of about $20 \mathrm{~kg}$; the preliminary period lasted for 12 days, the experimental one, for 5 days. The animals were divided into 5 equal groups. The pigs of the control group were fed a standard diet without feed antibiotics. The other groups were fed diets supplemented with a feed antibiotic, flavomycin, $20 \mathrm{ppm}$ (diet 2), oregano essential oils (Ecostim, Farmwet), 0.05\% (diet 3), mannan-oligosaccharide (Bio-Mos, Alltech Inc.), $0.1 \%$ (diet 4), or Lactobacillus plantarum, $1 \times 10^{9} \mathrm{cfu} /$ head/day (diet 5). The diets contained $13 \mathrm{MJ}$ EM, $178 \mathrm{~g}$ crude protein and $10.4 \mathrm{~g}$ lysine.

The chemical composition of feeds, faeces, and the $\mathrm{pH}$ of faeces were determined using standard methods. Faeces for microbial analysis were collected during the last 4 days. The bacterial group and species determined included Lactobacilli (MRS agar, Merck) and Escherichia coli (Chromocult agar, Merck). The concentration of short-chain fatty acids (SCFA) was determined by gas chromatography. Microbial enzyme activity in the faeces was measured by the rate of p- or o-nitrophenol release from their nitrophenylglucosides according to the modified method proposed by Djouzi and Andrieux, as described by Juśkiewicz et al. (2002).

The results obtained were elaborated statistically by one-factor analysis of variance in an orthogonal design using Statistica version 6.1.

\section{RESULTS}

Diet supplementation with different feed additives had no influence on the digestibility of most nutrients (Table 1).

Faecal bacterial populations (E. coli and Lactobacilli spp.) were not affected by diet composition. The lowest value of faecal $\mathrm{pH}$ was observed in the group fed a diet supplemented with an antibiotic and MOS, and the highest, in the group fed a diet containing oregano.

The activity of bacterial $\beta$-gluctosidase and $\beta$-glucuronidase did not differ among all dietary treatments. Diet supplementation with an antibiotic increased the activity of $\alpha$-galactosidase, $\alpha$-glucosidase and $\beta$-galactosidase. The concentration of total and particular SCFAs in the faeces was generally not affected by dietary treatments. Only the faecal concentration of butyric acid in the group fed a diet with an antibiotic and MOS was significantly higher, compared with probiotic treatment. 
Table 1. Nutrient digestibility and the microbial status of faeces

\begin{tabular}{|c|c|c|c|c|c|c|}
\hline \multirow{2}{*}{ Item } & \multicolumn{5}{|c|}{ Diet } & \multirow{2}{*}{ SEM } \\
\hline & Control & Flavomycin & Oregano & MOS & L. plantarum & \\
\hline \multicolumn{7}{|l|}{ Digestibility coefficients, $\%$} \\
\hline organic matter & 83.4 & 81.5 & 81.1 & 81.4 & 82.9 & 0.45 \\
\hline crude protein & 74.8 & 72.2 & 72.6 & 73.2 & 75.2 & 0.76 \\
\hline ether extract & $41.0^{\mathrm{a}}$ & $30.7^{\mathrm{b}}$ & $30.4^{\mathrm{b}}$ & $30.4^{\mathrm{b}}$ & $41.0^{\mathrm{a}}$ & 1.64 \\
\hline crude fibre & $37.4^{\mathrm{a}}$ & $22.4^{\mathrm{b}}$ & $22.1^{\mathrm{b}}$ & $22.9^{\mathrm{b}}$ & $29.7^{\mathrm{ab}}$ & 2.21 \\
\hline $\mathrm{N}$-free extractives & 90.7 & 89.9 & 89.1 & 89.4 & 89.9 & 0.32 \\
\hline \multicolumn{7}{|l|}{ Bacterial count } \\
\hline Escherichia coli, $\log _{10}$ & 7.05 & 7.61 & 7.31 & 7.32 & 7.38 & 0.12 \\
\hline Lactobacilli spp., $\log _{10}$ & 7.31 & 8.17 & 7.10 & 7.48 & 7.88 & 0.18 \\
\hline $\mathrm{pH}$ & $6.14^{\mathrm{abc}}$ & $5.95^{\mathrm{c}}$ & $6.35^{\mathrm{a}}$ & $5.92^{\mathrm{c}}$ & $6.19^{\mathrm{ab}}$ & 0.04 \\
\hline \multicolumn{7}{|l|}{ Enzyme activity, U/g } \\
\hline$\alpha$-glucosidase & $1.63^{\mathrm{ab}}$ & $1.90^{\mathrm{a}}$ & $1.35^{\mathrm{b}}$ & $1.78^{\mathrm{ab}}$ & $1.40^{\mathrm{b}}$ & 0.07 \\
\hline$\beta$-glucosidase & 0.65 & 0.87 & 0.65 & 0.89 & 0.65 & 0.04 \\
\hline$\alpha$-galactosidase & $2.92^{\mathrm{b}}$ & $6.16^{\mathrm{a}}$ & $3.13^{\mathrm{b}}$ & $3.71^{\mathrm{b}}$ & $3.63^{\mathrm{b}}$ & 0.25 \\
\hline$\beta$-galactosidase & $5.44^{\mathrm{b}}$ & $8.18^{\mathrm{a}}$ & $5.93^{\mathrm{b}}$ & $5.62^{\mathrm{b}}$ & $6.61^{\mathrm{ab}}$ & 0.29 \\
\hline$\beta$-glucuronidase & 0.50 & 0.45 & 0.79 & 0.50 & 0.73 & 0.05 \\
\hline \multicolumn{7}{|l|}{ SCFA concentration, $\mu \mathrm{mol} / \mathrm{g}$} \\
\hline acetate & 52.3 & 46.1 & 49.4 & 55.3 & 52.2 & 1.64 \\
\hline propionate & 20.0 & 19.8 & 18.1 & 22.3 & 20.5 & 0.85 \\
\hline isobutyrate & 3.1 & 3.3 & 3.2 & 3.3 & 3.1 & 0.10 \\
\hline butyrate & $11.5^{\mathrm{ab}}$ & $14.3^{\mathrm{a}}$ & $10.7^{\mathrm{ab}}$ & $13.7^{\mathrm{a}}$ & $9.9^{\mathrm{b}}$ & 0.58 \\
\hline isovalerate & 3.2 & 3.3 & 3.2 & 3.1 & 3.0 & 0.12 \\
\hline valerate & 4.8 & 4.8 & 4.0 & 4.9 & 4.4 & 0.20 \\
\hline
\end{tabular}

$\mathrm{a,b}-\mathrm{P} \leq 0.05$

\section{DISCUSSION}

In our study, particular dietary treatments had little effect on nutrient digestibility, population size of E. coli and Lactobacilli spp., and the activity of microbial enzymes in the faeces. Only the addition of an antibiotic increased the activity of $\alpha$ - and $\beta$-galactosidase, as compared with the other groups.

The application of antibiotics did not reduce the total bacterial count in the digestive tract (Hillman, 2001). A reverse tendency, i.e. a decrease in the bacterial enzyme activity caused by an antibiotic, was observed in an experiment on turkeys (Juśkiewicz et al., 2004). It should be noted that the potentially harmful activity of bacterial $\beta$-glucuronidase was not influenced by the experimental treatments.

The concentration of SCFAs in the faeces was relatively low and generally unrelated to the experimental factors. SCFA, as an end-product of bacterial fermentation in the hind gut, are actively and quickly absorbed through the colonic wall or used by colonic cells. However, in an experiment performed by $\mathrm{Xu}$ et al. (2005) dietary FOS significantly enhanced faecal SCFA concentrations compared with diets without FOS or with antibiotics. Differences in the bacterial 
fermentation processes in the colon of animals are responsible for the decrease in the faecal $\mathrm{pH}$ observed in antibiotic and MOS groups.

\section{CONCLUSIONS}

It can be concluded that the supplementation of diets for growing pigs with flavomycin, oregano, MOS or Lactobacillus plantarum did not affect nutrient digestibility. Faecal bacterial populations (E. coli, Lactobacilli spp.) were not affected by diet composition, either. Diet supplementation with oregano, MOS and $L$. plantarum did not increase the activity of microbial enzymes or the concentration of short-chain fatty acids in the faeces of pigs.

Dietary supplementation with different feed additives had a null or only small effect on the digestibility of nutrients and microbial status of faeces.

\section{REFERENCES}

Hillman K., 2001. Bacteriological aspects of the use of antibiotics and their alternatives in the feed of non-ruminant animals. In: P.C. Garnsworthy, J. Wiseman (Editors). Recent Advances in Animal Nutrition. Nottingham, pp. 107-134

Juśkiewicz J., Zduńczyk Z., Wróblewska M., Oszmiański J., Hernandez T., 2002. The response of rats to feeding with diets containing grapefruit flavonoid extract. Food Res. Int. 35, 201-205

Juśkiewicz J., Zduńczyk Z., Jankowski J., 2004. Selected parameters of gastrointestinal tract metabolism of turkeys fed diets with flavomycin and different inulin contents. World Poultry Sci. J. 60, 177-185

Xu C., Ji. C., Ma Q., Chen X., 2005. Effects of fructooligosaccharides on performance, VFA concentration and enteric morphology in piglets. J. Anim. Feed Sci. 14 (in press)

\section{STRESZCZENIE}

\section{Wpływ dodatków paszowych na strawność składników pokarmowych i status mikrobiologiczny kału świń}

Celem badań było określenie wpływu różnych dodatków paszowych (flawomycyna, oregano, MOS lub Lactobacillus plantarum) dodawanych do mieszanek dla rosnących świń (m.c. $20 \mathrm{~kg}$ ) na strawność składników pokarmowych oraz status mikrobiologiczny kału.

Zastosowanie $\mathrm{w}$ mieszankach różnych dodatków paszowych nie zróżnicowało strawności większości składników pokarmowych. Populacja bakterii w kale (E. coli, Lactobacilli spp.) nie była zróżnicowana pomiędzy grupami. Dodatek oregano, MOS i L. plantarum nie wpłynął na wzrost aktywności enzymów i LKT w kale świń. 